\title{
HOU SING PURCHASES AND THE DYNAMICS OF HOUSING WEALTH
}

Otympia Bover

Documentos de Trabajo N. 1036

\section{baN DO DE ESPANAa}

\author{
Eurosistema
}


HOUSING PURCHASES AND THE DYNAMICS OF HOUSING WEALTH 
HOUSING PURCHASES AND THE DYNAMICS

OF HOUSING WEALTH

Olympia Bover ${ }^{(*)}$

BANCO DE ESPAÑA

(*) Research Division, Banco de España. I am grateful for useful comments and suggestions to Manuel Arellano, Steve Bond, Martin Browning, Janice Eberly, Tullio Jappelli, Philipp Kircher, John Muellbauer, Enrique Sentana, Javier Suárez, Annette Vissing-Jorgensen, Guglielmo Weber, and participants at the CES Conference on Household Finance in Athens, September 2010. I would also like to give special thanks to Jorge Martínez Pagés, Julio Rodríguez, and Pilar Velilla for their help with the aggregate data. 
The Working Paper Series seeks to disseminate original research in economics and finance. All papers have been anonymously refereed. By publishing these papers, the Banco de España aims to contribute to economic analysis and, in particular, to knowledge of the Spanish economy and its international environment.

The opinions and analyses in the Working Paper Series are the responsibility of the authors and, therefore, do not necessarily coincide with those of the Banco de España or the Eurosystem.

The Banco de España disseminates its main reports and most of its publications via the INTERNET at the following website: http://www.bde.es.

Reproduction for educational and non-commercial purposes is permitted provided that the source is acknowledged.

() BANCO DE ESPAÑA, Madrid, 2010

ISSN: 0213-2710 (print)

ISSN: 1579-8666 (on line)

Depósito legal: M. 52623-2010

Unidad de Publicaciones, Banco de España 


\section{Abstract}

I model the purchase behavior of main and secondary housing by Spanish households using the panel sample from the first two waves of the Spanish household finance survey (EFF). I estimate discrete hazard models using retrospective and within-period purchase sequences. I also estimate an (S,S) model combining transactions data with longitudinal information on household wealth and housing stock values. I look at the role of adaptive expectations about the rate of return on housing and find they have a positive and significant effect on the demand for houses. This is true for historical and within-period purchase probabilities as well as for the target ratio of housing wealth to total wealth. The volatility of house price growth has a negative effect on purchases for investment but a positive one on purchases for consumption.

Keywords: Household finance, house purchases, secondary homes, housing returns, adaptive expectations, $(\mathrm{S}, \mathrm{s})$ rule.

JEL classification: D14, G11 


\section{Resumen}

En este trabajo se modelizan las decisiones de compra de vivienda principal y secundaria por parte de los hogares españoles utilizando la muestra panel proveniente de las dos primeras olas de la Encuesta Financiera de las Familias (EFF). Se estiman modelos de tasas de compra utilizando secuencias de compra retrospectivas y entre olas. También se estima un modelo $(\mathrm{S}, \mathrm{S})$ combinando datos de transacciones con información longitudinal acerca de los valores de la riqueza del hogar y de su stock de viviendas. Se analiza el papel de las expectativas adaptativas acerca de la tasa de rendimiento de la vivienda y se encuentra que tienen un efecto positivo y significativo sobre la demanda de viviendas. Esto es así tanto para las probabilidades de compra históricas y entre olas como para la ratio objetivo de riqueza en vivienda sobre riqueza total. La volatilidad del crecimiento en los precios de la vivienda tiene un efecto negativo en las compras para inversión pero positivo en las compras para consumo.

Palabras clave: Modelo (S,s), expectativas adaptativas, compra de vivienda, finanzas de los hogares, rendimiento de la vivienda, viviendas secundarias.

Códigos JEL: D14, G11. 


\section{Introduction}

In this paper I model the purchase behavior of main and secondary housing by Spanish households using the panel sample from the first two waves of the Spanish household finance survey (EFF). I estimate discrete hazard models using retrospective and within-period purchase sequences. I also estimate an $(S, s)$ model combining transactions data with longitudinal information on household wealth and housing stock values. The latter allows to disentangle the effects of observable determinants on target values vs. inaction range in transaction probabilities. Particular attention is paid to the effect of the expected rates of housing return on purchase probabilities and in providing some light on whether the effect takes place through a change in the desired proportion of housing wealth or through a change in the timing of transactions.

I consider the role of adaptive expectations based on the extrapolation of past house price increases. This is of interest for several reasons. First, if households (or a fraction of them) respond to extrapolative price expectations, their behaviour may lead to speculative bubbles. That is, if they expect that a past high rate of price appreciation will continue into the future, further price increases and self-fulfilling expectations may follow, at least for a while. Moreover, housing returns in our period of analysis exhibit substantial serial correlation (a common finding first noted in Case and Shiller, 1989). Finally, previous price patterns have been found to be associated with subjective expectations about asset prices in investors' surveys (eg. Vissing-Jorgensen, 2003, on stocks and Hui, 2004, on real estate).

In some countries the housing market cannot be properly analyzed by focusing on main residence housing without considering secondary housing. In Figure 1 we report the proportion of main vs. other housing for various countries according to their latest Census. We see that the share of housing units that are used as secondary residence or kept empty varies from $35.4 \%$ in Greece to $1.3 \%$ in the Netherlands. Obviously, Greece, Spain, and Portugal are countries with significant vacation housing. However, in Spain according to the same sources, $48 \%$ of this other housing units are kept empty ( $15.1 \%$ of the total stock). ${ }^{12}$

\footnotetext{
${ }^{1}$ According to the 2001 Spanish Census (source: National Statistics Institute (INE)) there were 14.2 million main residence housing units, 3.4 million units used as secondary housing, and 3.1 million units that were empty. More recent figures by the Ministry of Housing relating to 2008 estimate a total of 16.7 million main residences and 8.4 million secondary or empty housing units (ie $33.4 \%$ of the total stock).

${ }^{2}$ Figure 1 classifies dwellings by their use, and therefore it may understate the importance of secondary housing from the perspective of ownership. That is, a dwelling may be the main residence of a renter and at the same time a secondary housing property of its owner.
} 


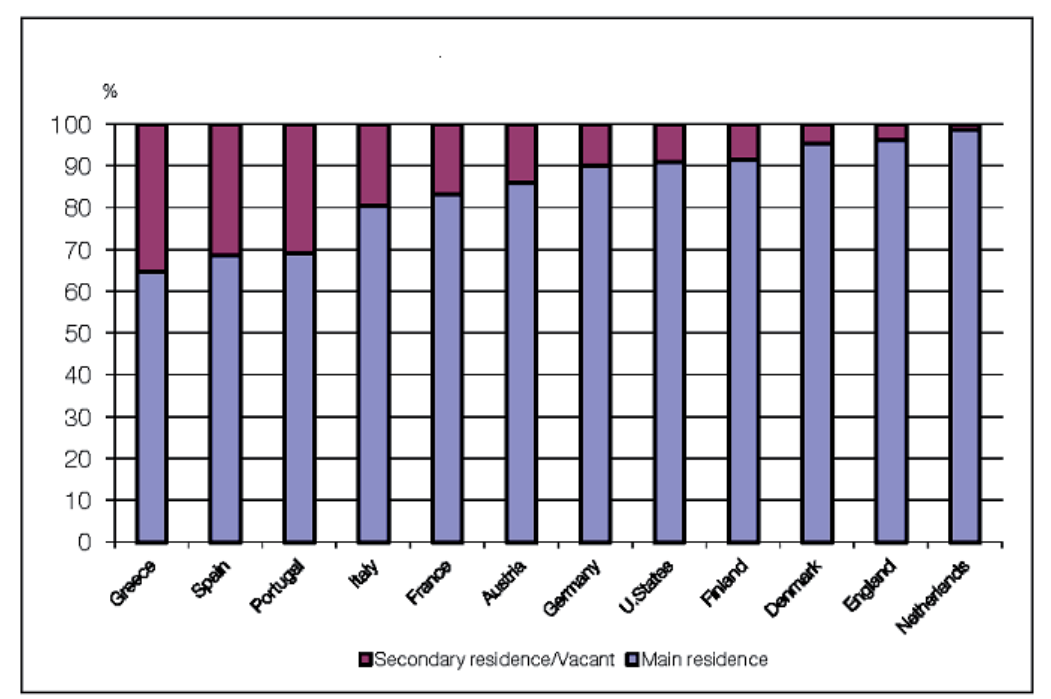

Figure 1: Composition of the dwelling stock

Market prices of housing are obtained by collecting individual prices of properties sold in a time interval. These transaction prices are then applied to comparable housing that has not been in the market during the period. However, the number of transactions in the housing market relative to the stock of housing is very small by comparison with other asset markets (a point made by Piazzesi and Schneider, 2009). ${ }^{3}$ Therefore, understanding changes in purchase and sale behavior is potentially important for understanding housing market fluctuations.

This paper is an empirical exploration of the determinants of house purchases and housing wealth on the EFF data. A goal of the paper is to provide an empirical framework to extract the potential of these data for housing demand analysis.

The data I have contains information on household purchases during a period of five years between 2002 and 2006 covered by the first two waves of the EFF. The data also contains retrospective information on the purchase history of housing asset holdings at the beginning of the sample period. Moreover, there is also information about the value of housing wealth, other assets, and income at the beginning and the end of the observation period. Information on sales is much less detailed. The data lacks retrospective information on sales and in the between waves period I observe if a sale has taken place but not in which of the three years.

Firstly, I use retrospective purchase histories to estimate hazard functions for the period

\footnotetext{
${ }^{3}$ In 2003 the share of housing transactions in the number of dwellings for the euro area was 2.17\% (Source: Structural housing indicators for the euro area, ECB based on national data).
} 
1980-2001. In this way I can exploit significant time series variation in market prices and interest rates. However, only time invariant household characteristics such as education and age are available for the historical spells. So, these results can be regarded as a model of the "initial conditions" data for the in-sample purchase sequences.

Secondly, I construct purchase spells for the 2002-2006 period and estimate logistic hazard models of the timing of primary and secondary house transactions. Since I observe whether secondary properties are used for own consumption or not, I also consider multinomial and conditional probability models.

Note that there is a fundamental difference between what I do (looking at purchase probabilities at the time the decision is made) and first-generation studies of micro housing demand, which looked at cross-sectional probabilities of owning housing assets. I look at the determinants of an annual purchase rate (around $1.6 \%$ on average in my data) whereas first generation studies looked at the determinants of being observed holding secondary housing ( $26 \%$ on average).

Finally, I model housing purchase and sale behavior as an $(S, s)$ rule. Specifically, I assume that because of lumpy transaction costs, only households whose beginning-of-period state variable (the ratio of housing wealth to total wealth) is far enough from their target level engage in transactions during the period. For those households the end-of-period state variable reveals the target and the change during the period reveals the rule's bandwidth. Identification of this model requires panel data on wealth and transaction indicators, which I have. The advantage of the $(S, s)$ approach is that it makes it possible to identify separate effects of observable determinants on target values and inaction-range in transaction probabilities. Alternatively it can be regarded as a flexible dynamic model of the share of housing wealth to total wealth.

The two approaches (logistic hazards and $(S, s)$ model) provide complementary information. The $(S, s)$ model exploits wealth data to place a tight structure on transaction probabilities, which allows distinction between two channels of the effect of expected returns, whereas logistic hazards allow me to have a more flexible empirical specification to exploit annual purchase information and retrospective data.

A recent micro empirical literature has examined the purchase history of PSID consumers in the US (e.g. Dunn, 2003; Han, 2009; Bajari et al. 2010). These papers focus on the moving (mostly upgrading) decisions of existing homeowners, abstracting from first-time buyers and 
tenure choice. In this paper I also abstract from tenure choice (home ownership is much larger in Spain than in the US) but I pay particular attention to transactions involving secondary housing since, contrary to other countries, these account for a significant fraction of total transactions in the Spanish housing market. ${ }^{4}$ In contrast, in Spain upgrading/downgrading in primary housing has been of less importance. This means that in a large number of cases a housing transaction does not involve a simultaneous purchase and sale (as is the case when housing market transactions are dominated by upgrading or downgrading of main housing).

The starting point is the assumption that the extra cost of renting as opposed to owning is so high that in our context all "adult" agents are essentially home owners. This may be due to a combination of income tax advantages of owning, rental market regulation, and the rental externality of maintenance costs (Henderson and Ioannides, 1983), among other things. So we abstract from the housing tenure choice and focus on households with a positive housing stock. Given the very high ownership rates of EFF households this is not a strong assumption. ${ }^{5}$

The remainder of the paper is organized as follows. Section 2 describes the data. Section 3 presents the purchase hazard models and reports the estimated results. This is done both for between wave purchases and for retrospective purchase histories. Multinomial hazards for investment or consumption use are also presented. A time-aggregated hazard for the probability of a sale over the three-year period is also reported. Section 4 lays out the $(S, s)$ model considered in this paper, describes its maximum likelihood estimation and provides the $(S, s)$ model results. Finally, Section 5 concludes. A supplementary web site appendix contains additional details of several results discussed in the main text. ${ }^{6}$

\section{Data and descriptive statistics}

\subsection{Survey micro data on house purchases and wealth}

Household data The data come from the first two waves of the Spanish Survey of Household Finances (EFF). This survey contains detailed information on household assets,

\footnotetext{
${ }^{4}$ According to the EFF 2002 and the US Survey of Consumer Finances 2001, 82\% of Spanish households own their main residence compared to $68 \%$ in the US. Moreover, in Spain $30 \%$ of households own some other real estate property compared to $17 \%$ in the US (see Bover et al., 2005).

${ }^{5}$ For a duration analysis on the determinants of saving time til first purchase of main residence see Guiso and Jappelli (2002). See also Andrew and Meen (2003) for an analysis of the joint decision of new household formation and tenure choice using six waves of the British Household Panel Data (BHPS).

${ }^{6}$ The address is http://www.olympiabover.name/HD_Appendix.pdf.
} 
debts, income and consumption and has now been conducted on three occasions, at end2002/beginning-2003, end-2005/beginning-2006 and at end-2008/beginning-2009, but data for the third wave are still not available. The EFF is specially designed for the study of household wealth. While providing a representative picture of the structure of household assets and debt it incorporates an oversampling of wealthy households based on individual wealth tax files. ${ }^{7}$ In addition, in the 2005 wave approximately half of the households interviewed in 2002-2003 were interviewed again.

The aim of the survey is to collect rich information on households assets, debts and income together with socioeconomic variables relative to households and their members and spending information. There is detailed information on owner occupied residence, other real estate, businesses, vehicles, all types of financial assets, and debts. The wealth measure we use in the paper is total wealth defined as non-human assets. All assets are valued at market prices. Relevant for this paper, home owners are asked details (date of purchase, price at time of purchase, current value, use etc.) on their main residence and on up to three other main real estate properties together with detailed information on all asociated debts. ${ }^{8}$ We hence have a record of purchases (and the year the purchase was made) as long as the household still owns the property at the moment of the EFF interview. To obtain information about between-wave sales we compare the three more important properties held by panel households in 2002 and 2005 and take as sold a property declared in 2002 but not in 2005. We do not know in which of the intervening years the observed sale took place.

Sample The size of the EFF panel component is 2580 households. In general, the characteristics of the panel sub-sample population do not differ from those of the population as a whole except for the youngest and those not owning their main residence (see Bover, 2008). For our purposes we eliminate from the sample households where the head has changed (31 observations, $1.3 \%$ of the population) and those who did not own their main residence in both waves (383 observations, 17.6\%). When studying the hazards of purchases between the two waves we further restrict the sample to those having in 2005 less than 3 other housing

\footnotetext{
${ }^{7}$ See Bover (2004).

${ }^{8}$ One characteristics of wealth surveys is high item non-response rates. In such circumstances, it is problematic to work with only available cases and ignore non-response. The Banco de España, provider of the EFF, facilitates imputed values to allow use of the data using complete data methods. The imputation methods used are stochastic to preserve the observed distribution of variables and covariances between them. Multiply imputed data sets are available to take into account uncertainty about imputed values. All figures reported in the paper make use of the five multiply imputed data sets.
} 
properties bought before 2002 or inherited (1.6\% had three or more, 440 observations). Our final sample size is 2078 households. To identify sales and estimate the $(S, s)$ model we further restrict the sample to those owning less than four properties in 2005. Finally, a small number of observations involving contradictory or implausible information when comparing the information in the two waves were dropped as well.

Some descriptive statistics Table 1 presents the fraction of owners of main and secondary properties. Aside from a very high owner occupier rate (86\%), a large proportion Spanish households own other housing $(28 \%) .{ }^{9}$ The majority of households use their other housing for their own consumption (vacation home, own business activities) but a sizeable proportion use it exclusively as an investment (renting or vacant).

Table 1

\begin{tabular}{lcc}
\multicolumn{3}{c}{ Ownership of main and other housing (\%) } \\
\hline & 2002 & 2005 \\
\hline Home owners & 85.9 & 85.8 \\
Own other housing & 24.5 & 27.9 \\
Investment & 36.2 & 42.9 \\
Consumption & 56.9 & 48.1 \\
Mixed & 6.9 & 9.0 \\
Own 1 other housing & 19.8 & 21.9 \\
Investment & 37.9 & 44.4 \\
Consumption & 62.1 & 55.6 \\
\hline
\end{tabular}

Gifts and bequests do not seem to have played so far a predominant role as a determinant of house ownership rates. According to the EFF2002, one out of ten households have inherited (or received as a gift) their main residence and one in four of those having one second house have inherited it. It is foreseable that gifts and inheritances will play a larger role in the future given the sharp reduction in the number of children of Spanish households since the late 1970s.

Table 2 gives the fraction of households that purchased or sold housing during the sample period. As mentioned earlier, the proportion of households changing main residence is low (1.8\%), but the proportion of households buying other housing during the three year period between waves is $5.2 \%$. As expected, purchases of other housing decrease with age. Moreover, households who owned other housing previously were more prone to buy some more during this period $(6.1 \%)$ than those wo did not (4.9\%). Finally, $56 \%$ of the households finance

\footnotetext{
${ }^{9}$ In Spain there are income tax incentives to owning the main residence but not to owning other housing.
} 
their purchase of other housing during this period using credit, while only $26 \%$ did so for the 1980-2001 period purchases (not shown in tables).

Table 2

\begin{tabular}{lc} 
Households doing transactions 2002-2006 (\%) \\
\hline $\begin{array}{l}\text { Home movers } \\
\text { Purchased other housing }\end{array}$ & 5.8 \\
& \\
$\quad$ Investment & 2.8 \\
Consumption & 2.4 \\
& \\
Age $<35$ & 7.4 \\
$35 \leq$ Age $<45$ & 7.3 \\
$45 \leq$ Age $<55$ & 6.4 \\
$55 \leq$ Age $<65$ & 6.1 \\
$65 \leq$ Age $<75$ & 1.1 \\
Age $\geq 75$ & 0.2 \\
$\quad$ & \\
$\quad$ With previous other housing & 6.1 \\
$\quad$ Without prev. other housing & 4.9 \\
$\quad$ & \\
Sold previous main residence & 1.4 \\
Sold other housing & 8.7
\end{tabular}

The fraction of households who sold (10\%) is larger than the one who bought (7\%). The difference between the two can be accounted for by purchases by new households (not covered by the EFF panel sample) who buy from other households (second hand housing units) or directly from developers (newly built dwellings). ${ }^{10}$

There is a question in the EFF survey about whether a household has sold any real estate property in the last twelve months, which $2 \%$ of households respond affirmatively. Although we cannot rely on it to determine households who sold housing between waves, ${ }^{11}$ it provides a coherency cross-check to the number of sales obtained by comparing properties held in the two waves. In particular, the figures are compatible when considering that this question was asked only to $40 \%$ of households (those owning other real estate properties at the time of the interview or having owned in the past 12 months), it refers to one third of the between waves time span, and over half of real estate transactions are housing ones. ${ }^{12}$

\footnotetext{
${ }^{10}$ A fraction of EFF households who bought acquired housing from newly built developments.

${ }^{11}$ Due to the inclusion of real estate other than housing, such as land, commercial property, parking lots, and the three years span between waves.

${ }^{12} 60 \%$ of the number of real estate properties (other than main housing) held by households with at most three properties is housing.
} 
A time pattern of retrospective purchases (still held at the time of the EFF interview) by age groups is shown in Figure 2. The elder buy significantly less housing at any given market conditions. In contrast, for working-age mature households (between 45 and 64) we can clearly appreciate the reduction in the number of purchases during the slowdown in housing market returns of the late 1980s. ${ }^{13}$ The effect of the housing cycle is less visible for younger households than for the 45-64, possibly due to the differential importance of life-cycle effects.

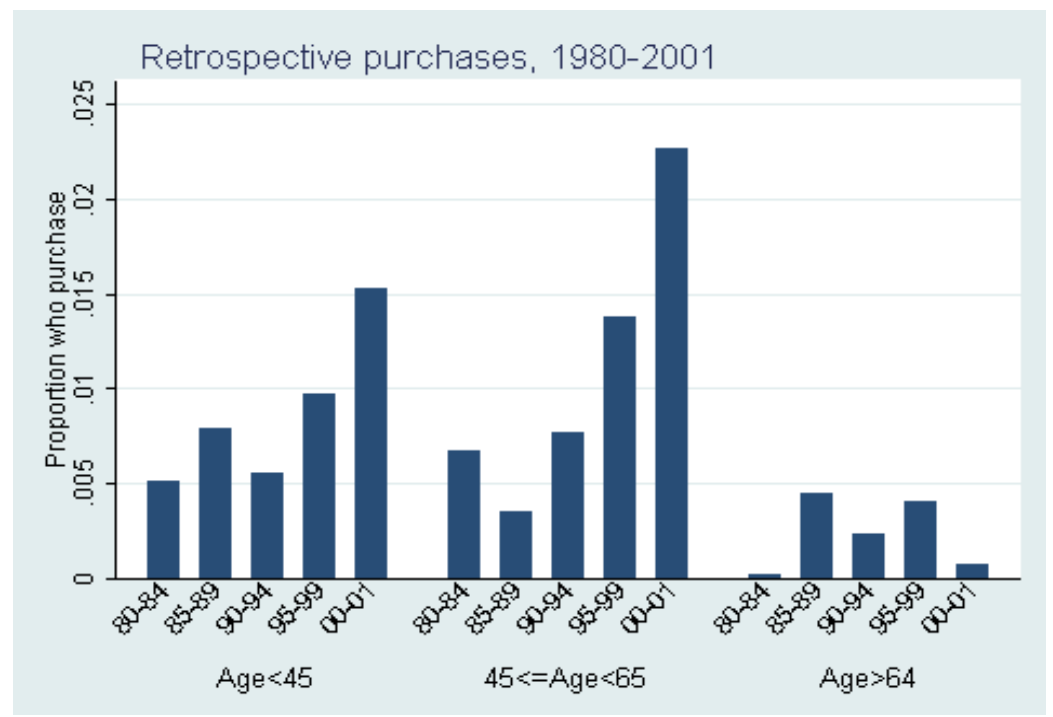

Figure 2: Retrospective purchases by 2002 age groups

Finally, Table 3 provides the percentiles of the distribution of the housing wealth share in 2002 and 2005. Housing wealth is a high proportion of Spanish household wealth. For example, the median share of housing wealth to total wealth is almost $90 \%$ in 2005 .

Table 3

Distribution of housing wealth share

\begin{tabular}{ccc}
\hline Percentile & 2002 & 2005 \\
\hline 10 & .37 & .39 \\
20 & .55 & .57 \\
30 & .69 & .70 \\
40 & .79 & .80 \\
50 & .86 & .88 \\
60 & .91 & .92 \\
70 & .95 & .96 \\
80 & .98 & .98 \\
90 & .99 & .99 \\
\hline
\end{tabular}

${ }^{13}$ See Figures 3,4, and 5 below. 
Aggregate EFF information on transactions Here we discuss the aggregate information on housing transactions and its consistency with the survey information provided by the EFF. We conclude that the two are broadly consistent with each other. In Spain aggregate information on the number of housing transactions is available since $2004 .^{14}$ At the 2005 peak there were 987,000 transactions ( $56 \%$ of them corresponding to newly built units). ${ }^{15}$ These were down to 414,000 in 2009. Over the period 2002-2005 the information available points to around 850,000 per year.

In the EFF we have information on the number of real estate properties held by individual households at each wave and have details on the main residence and on the three most valuable other real estate properties. ${ }^{16}$ With the EFF panel sample we expect to capture changes in the main residence for 2002 owner occupiers but not new households (or previously renting households) buying their main house, because of the nature of the panel sample. ${ }^{17}$

Comparing characteristics of their 2002 and 2005 main residence, and taking into account population weights, owners changing main residence account for 118 thousand purchases per year for the three-year period between waves. Similarly, the information contained in the details of the three more valuable properties provides around 223 thousand purchases of secondary housing per year.

However, the three other properties account for $67 \%$ of the total number of other properties held by households and for an equal proportion of the increase in the number of properties between the 2002 and 2005 waves. Thus the EFF information on second housing purchases would imply a total number of second housing purchases per year of the order of 330 thousand. ${ }^{18}$ Finally, 1.5 million new households were formed in the three years between waves. Assuming $60 \%$ of them buy their main residence, they would account for 300 thousand purchases per annum. ${ }^{19}$ We believe therefore that the information on housing purchases

\footnotetext{
${ }^{14}$ The data from 2007 based on Registry information may be found at the National Statistics Office (INE) website. Data for 2005 and 2006 are available directly from the Registrar records, and data for 2004 have been estimated using housing transactions collected by the Housing Ministry based on Notary information. Data for 2002 and 2003 were constructed by Julio Rodríguez using the rate of change of the number of mortgages from Banco de España.

${ }^{15}$ At the beginning of $20062.7 \%$ of transactions were to non Spanish resident buyers.

${ }^{16}$ Details include year of purchase, value at purchase and at the time of the interview, type and use of the property, whether it was financed with a loan, details on the loan if still pending, etc.

${ }^{17}$ See Bover (2008).

${ }^{18}$ This is an upper bound since we may expect housing to be predominant among the most valuable properties although this is not always the case in the data.

${ }^{19}$ The information on the number of new households is derived from the 2002 and 2005 EFF cross-sections. The percentage of new household buyers is assumed taking into account the percentage of young households who own their main residence (average between 2002 and 2005 cross-section results).
} 


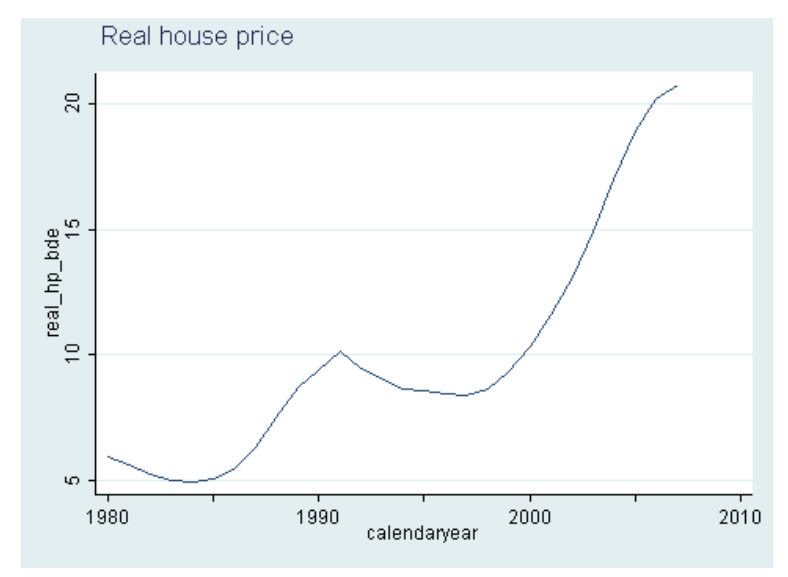

Figure 3: Real house prices

contained in the EFF is consistent with the aggregate information. ${ }^{20}$

\subsection{Market prices, expected returns on housing, and volatility}

Complementary data sources The evolution of aggregate house prices $(H P)$ and interest rates $(i)$ is shown in Figures 3 and 4. The rate of return on housing measured as $(\Delta \ln H P-i)$ is also shown. Housing returns peaked in the second part of the 1980s and in the first part of the 2000 s, reaching $8 \%$ and $12.6 \%$ respectively.

The house price series adopted in this paper was constructed at the Banco de España splicing data from three sources. Data from the Ministry of Infrastructure and Transport are used when available (from 1987 to 2004). Earlier data were obtained using the rate of change of Madrid house prices (available from Tecnigrama from 1976) but adjusting for the larger volatility of the Madrid data. After 2004 data were constructed using rates of change of the new series produced by the Housing Ministry. In an attempt to provide some variation in the start of period rate of return when estimating the $(S, s)$ model (and the time-aggregated hazards for sales) we also make use of house price series at the province level (Source: Sociedad de Tasación; starting in 1985).

There is not much choice either for a consistent series on interest rates throughout the historical period. Only the interest rate for new mortgages to households and non-profit institutions is available (Source: Banco de España; available since 1980 and hence the starting period of our retrospective analysis). For the period between waves we calculate an income group specific rate using the EFF information on the interest rate paid by households on the

\footnotetext{
${ }^{20}$ We do not expect the amount of housing bought and sold by the same households between waves to be a large proportion of transactions.
} 


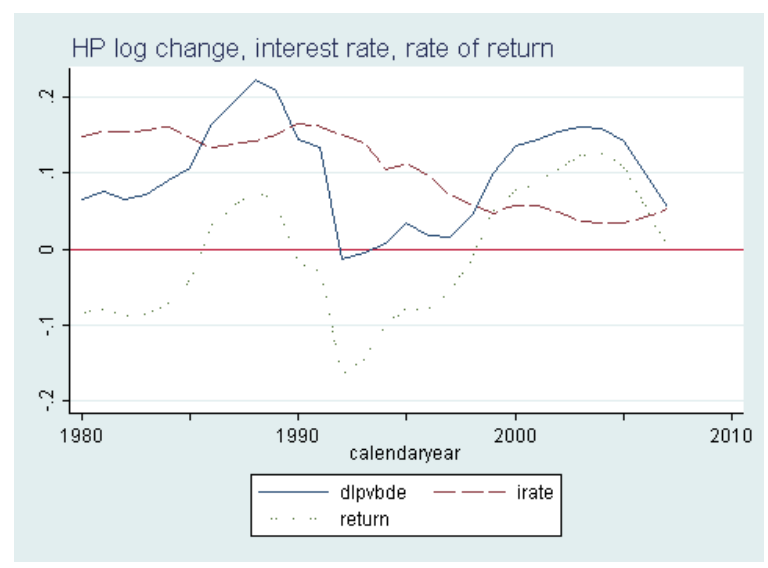

Figure 4: House price growth, interest rate, and rate of return

main loan taken to buy their main residence. ${ }^{21}$ Since a large fraction of households do not currently have any mortgage, we use the mean of that rate for each of the income groups. Time variation is provided by the previously mentioned aggregate new mortgage rate.

Finally, income and unemployment rate at the province level, which are used for robustness checks, are available from the regional accounts and the Labour Force Survey, respectively (Source: National Statistics Office, INE). The aggregate retail price index (Source: National Statistics Office, INE) has been used to obtain real magnitudes.

Expected returns on housing To investigate the effect of expected future house price developments on the purchase decisions of households, expectation measures need to be constructed. In this paper we look at the role of adaptive expectations based on the extrapolation of past price increases. We use a forecast of the house price change over the next five years using current and past information to measure the expected rate of return as

$$
E_{t}\left(\Delta \ln H P_{t+5, t}\right)-i_{t}
$$

where the expected variation in house prices is measured over a five year period. ${ }^{22}$ This time length seems reasonable given transaction costs involved. To obtain these forecasts we estimate an $A R(2) A R C H(1)$ model using the annual data with the following results:

\footnotetext{
${ }^{21}$ We consider six income groups.

${ }^{22}$ The five year increase is divided by 5 to keep an annual return base measure.
} 


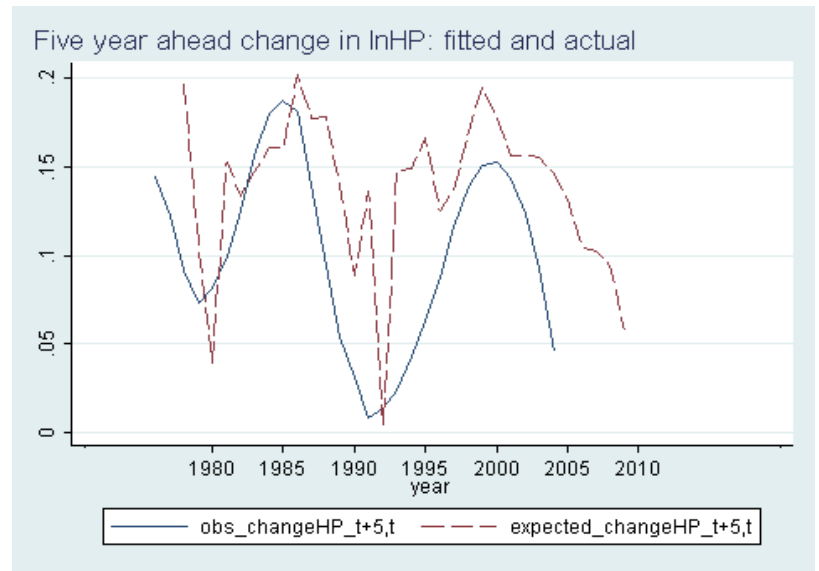

Figure 5: Expected house price growth

$$
\begin{aligned}
\Delta \ln H P_{t}= & 0.148+1.527 \Delta \ln H P_{t-1}-0.778 \Delta \ln H P_{t-2}+\widehat{u}_{t} \\
& (10.45)(14.84) \\
\operatorname{Volatility}\left(H P_{t}\right)= & 0.286 * 10^{-4}+2.958 \widehat{u}_{t-1}^{2} . \\
& (0.47) \\
& (t-\text { ratios in parentheses }) .
\end{aligned}
$$

At each period $t$, we forecast recursively future changes in house prices based on house prices up to $t .{ }^{23}$

These results show the predictability of house price growth $\left(R^{2}\right.$ is $\left.70 \%\right)$. A similar equation for housing returns produces an even higher $R^{2}(80 \%)$ due to the high predictability of interest rates during the period of analysis (similar to Case and Shiller, 1989).

Figure 5 shows the expected 5 years ahead change in house prices and the observed one. We see that the expected change using only information up to period t captures the main observed movements with some deviations.

I have also considered an $A R(2) A R C H(1)$ model which includes the change in the unemployment rate (lagged one period) as well. The predicted 5 years ahead change from this model tracks less well the actual observed change than the pure $A R(2) A R C H(1)$. In particular, there is an unreasonably large drop in the expected change at the beginning of the $1990 \mathrm{~s} .{ }^{24}$

\footnotetext{
${ }^{23}$ Similar approaches to measuring expected housing returns can be found in Han (2009) and Hwang and Quigley (2006).

${ }^{24}$ Moreover, actual future values of the change in the unemployment rate would be needed to forecast the
} 
When using house prices at the province level we fit an $\operatorname{AR}(1)$ model for each of the 50 provinces and construct expected returns in a similar way.

House price volatility Similarly, we use this model to construct 5 year ahead volatility measures to test for the effect of risk on housing purchases and in particular for hedging vs. financial effects. On the one hand an increase in house price uncertainty increases the financial risk of holding housing wealth but on the other hand it increases the incentives to hedge against future consumption cost risk for households who plan to consume more housing. Han (2009) disentangles these two effects of risk on main housing purchases with the help of a hedging propensity indicator based on the estimated probability of a household to roll over to a bigger house in the next 5 years. Here we avoid the potential endogeneity problems created by this indicator and examine the different effect of risk on purchases used for consumption and purchases used for investment.

There is limited variation in the volatility in the data except at spikes during the 1990s, the beginning of the 1980s and the latter part of the 2000s (which is why the estimated $A R C H$ coefficient is so large). There is therefore a better opportunity for identifying the effect of house price risk on housing demand in the context of the retrospective purchase histories than in the between waves analysis.

As an alternative to the previous model-based estimation of volatility I considered a measure of observed volatility by constructing a five-year moving window of the variances of observed $(\log )$ price changes. ${ }^{25}$ Figure 6 shows that the two measures are broadly consistent with each other, although the observed volatility measure shows larger variability, in particular during the 2002-2006 period.

\section{Discrete housing purchase hazards}

\subsection{Empirical approach}

In this section I present estimates of logistic hazard models of housing purchases. Firstly, using retrospective purchase histories I estimate hazard functions for the period 1980-2001. Next, using purchase sequences for the sample period I can relate the probability of changing the housing stock to additional controls like income.

expected change in house prices (or predicted values from an auxiliary forecast model for the unemployment rate).

${ }^{25}$ Banks, Blundell, Oldfield, and Smith (2010) use a similar measure of volatility. 


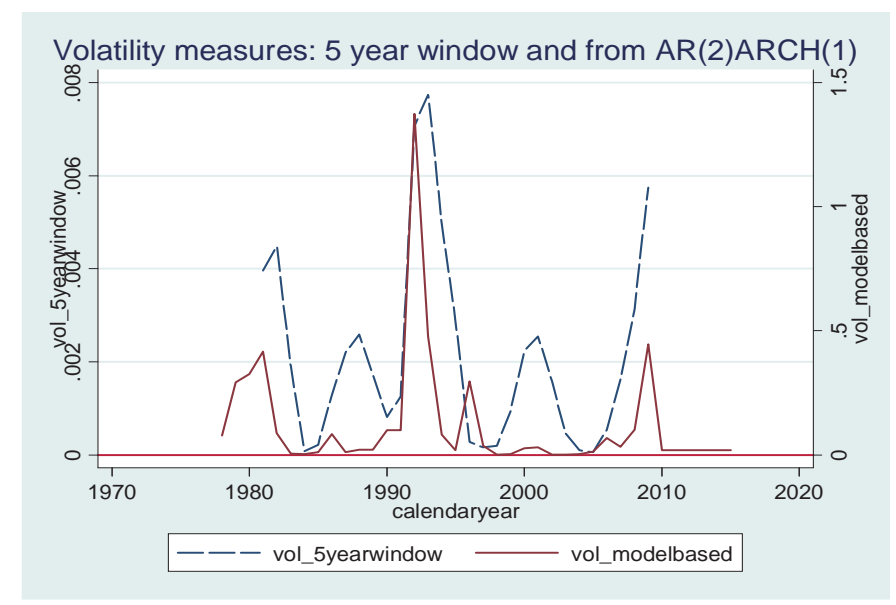

Figure 6: Volatility measures

The current sample of panel EFF households were interviewed twice in 2002/3 and $2005 / 6$. For these households we have two observations of their money values of assets and income. At each interview information was also collected on the year of purchase of properties in their current housing stock (with a specification of primary housing and up to three other properties), and about sales in the previous year.

From this information I construct within-sample sequences of purchase and sale spells covering the six-year period from 2002 to 2006. I also construct a historical sequence of purchases for the period 1980-2001 using the retrospective information, which was very useful despite its limitations. An advantage of the historical data is that I can exploit significant time series variation in market prices and interest rates. One limitation is that it is assembled from the perspective of the 2002 housing stock, so I cannot know if a household held but sold property prior to the start of the EFF. Another limitation is the lack of retrospective information on time-varying individual variables.

To model purchase probabilities I build from the likelihood of individual sequences. Consider, for example, a home-owning household since 1990 which purchased a secondary house in 2002 and a third one in 2004. The likelihood of observing such sequence is

$$
\begin{aligned}
& \operatorname{Pr}\left(B_{0}, B_{1}^{2002}, B_{2}^{2004}, \bar{B}_{3}^{2005}\right) \\
= & \operatorname{Pr}\left(\bar{B}_{3}^{2005} \mid B_{2}^{2004}, B_{1}^{2002}, B_{0}\right) \operatorname{Pr}\left(B_{2}^{2004} \mid B_{1}^{2002}, B_{0}\right) \operatorname{Pr}\left(B_{1}^{2002} \mid B_{0}\right) \operatorname{Pr}\left(B_{0}\right)
\end{aligned}
$$

I regard $B_{1}^{2002}$ and $B_{2}^{2004}$ as "complete" spells associated with the observed purchases (spells denoting time between transactions) whereas $\bar{B}_{3}^{2005}$ is an incomplete spell that captures the absence of transactions between 2004 and the end of the observation period. Then 
I can write

$$
\operatorname{Pr}\left(B_{2}^{2004} \mid B_{1}^{2002}, B_{0}\right)=h_{2}(2)\left[1-h_{2}(1)\right]
$$

where $h_{2}(t)$ is the hazard rate of purchasing a second other property $t$ periods since the previous transaction, conditioned on controls and the history of previous transactions. Purchase hazard rates for first or third other properties are similarly defined.

I specify logistic hazards, $h_{j}(t)=\left(1+e^{-s_{j}(t)}\right)^{-1}$ where $s_{j}(t)$ is a linear index of individual, spell, and calendar-time specific variables. Since the results for second and further other properties were fairly similar, I considered a common parametric model for the purchase hazard of all other property, using a separate model for main housing transactions.

For retrospective purchases (the modelling of the initial component $\operatorname{Pr}\left(B_{0}\right)$ in the previous factorization) I used a similar approach but since the length of period and the available controls were different I kept these specifications separate from the within-period probabilities.

The EFF households are asked if their secondary properties are used for own consumption or not. In an attempt to check for differences in the estimated effects according to the intended use of the housing purchased, I decomposed the hazard rate into separate transitions for purchases for consumption use and those for investment use. To do this I used a multinomial logit specification.

\subsection{Purchase hazards from retrospective histories}

Table 4 reports estimates of logistic hazard models from the historical data. For these retrospective hazards we consider only time invariant household demographic variables, namely age and education of the household head. More precisely, we extrapolate the age of the current head of household for each year during the period 1980 to 2001 and keep observations when the current head is over 24 years of age. The level of education attained for that retrospective period is assumed to be the same as the current one.

The first two columns differ in the treatment of the housing return variable: observed (column 1) and expected (column 2). Finally, column 3 is a variation of column 2 which includes a permanent income variable instead of the education dummies. ${ }^{26}$

Age and education variables are significant and education has a sizeable effect on the probability of having purchased secondary housing. The strong effect of age here is partly

\footnotetext{
${ }^{26}$ Permanent income is estimated using education dummies and a second order polynomial in age.
} 
picking up income and marital status, as we'll see in the estimates for the within-sample period.

The expected rate of return on housing has a significantly positive effect. To get a feeling for the size of the effects on the probability of purchasing secondary housing we calculate the probability of purchasing a secondary housing over the period 1980-2001 for various housing return rates (using the column 2 estimates). We first take as reference a household whose male head is aged 40, has secondary education, and no previous other housing. At the median expected return (4\%) the purchase probability is $1 \%$ while it increases to $1.7 \%$ when returns are expected to be high $(15 \%)$ and decreases to $0.4 \%$ when they are expected to be low (-15\%). For university educated household heads these probabilities are $2.5 \%, 4.2 \%$, and $1 \%$, respectively.

Table 4

Hazards for retrospective purchases Secondary housing, 1980-2001

\begin{tabular}{|c|c|c|c|}
\hline & 1 & 2 & 3 \\
\hline Secondary education & $\begin{array}{l}0.308 \\
(1.60)\end{array}$ & $\begin{array}{l}0.253 \\
(1.30)\end{array}$ & - \\
\hline University education & $\begin{array}{l}0.989 \\
(5.58)\end{array}$ & $\begin{array}{l}0.952 \\
(5.43)\end{array}$ & - \\
\hline Age & $\begin{array}{l}0.262 \\
(5.26)\end{array}$ & $\begin{array}{l}0.267 \\
(5.34)\end{array}$ & $\begin{array}{l}0.207 \\
(4.15)\end{array}$ \\
\hline Age squared & $\begin{array}{c}-0.003 \\
(5.20)\end{array}$ & $\begin{array}{c}-0.003 \\
(5.34)\end{array}$ & $\begin{array}{l}-0.002 \\
(4.36)\end{array}$ \\
\hline$\Delta \ln H P_{t, t-1}-i^{1}$ & $\begin{array}{l}3.992 \\
(4.01)\end{array}$ & - & - \\
\hline$\Delta \ln \widehat{H P}_{t+5, t}-i$ & - & $\begin{array}{l}4.956 \\
(3.85)\end{array}$ & $\begin{array}{l}4.910 \\
(3.87)\end{array}$ \\
\hline $\begin{array}{l}\text { Permanent income } \\
\text { (in thousand euros) }\end{array}$ & - & - & $\begin{array}{l}0.014 \\
(5.44)\end{array}$ \\
\hline Previous other housing & $\begin{array}{c}-0.245 \\
(1.32)\end{array}$ & $\begin{array}{c}-0.249 \\
(1.34)\end{array}$ & $\begin{array}{c}-0.247 \\
(1.33)\end{array}$ \\
\hline Constant & $\begin{array}{c}-10.649 \\
(9.07)\end{array}$ & $\begin{array}{c}-10.945 \\
(9.29)\end{array}$ & $\begin{array}{l}-9.621 \\
(8.39)\end{array}$ \\
\hline $\begin{array}{l}\text { McFadden's Pseudo } \mathrm{R}^{2} \\
\text { No. of observations } \\
\text { of which } \mathrm{n}^{\circ} \text { of purchases }\end{array}$ & 0.038 & $\begin{array}{c}0.040 \\
41,589 \\
666\end{array}$ & 0.040 \\
\hline
\end{tabular}

We also tested for the potential effects of other mortgage market conditions (aside from 
the interest rate) by including the index on credit conditions developed for the Spanish housing market in Oxford Economics (2009) similar to the one constructed for the UK by Fernandez-Corujedo and Muellbauer (2006). However, this proved insignificant.

The volatility term is not significant (not shown). This could be because of opposite effects of risks. Indeed a positive hedging effect is expected if other housing is purchased for own consumption needs while a negative one is anticipated because of the existence of financial risk. This is one motivation for the multinomial hazards analysis presented next.

Owning already other housing has an expected negative effect although not significant.

Investment vs. consumption use Table 5 reports multinomial logit estimates using purchase sequences from the historical data that exploit information about current use (own consumption vs. investment) of all secondary housing properties.

Table 5

Multinomial hazards for retrospective secondary housing purchases 1980-2001 Investment vs. consumption

\begin{tabular}{|c|c|c|c|c|}
\hline & \multicolumn{2}{|c|}{1} & \multicolumn{2}{|c|}{2} \\
\hline & Consumption & Investment & Consumption & Investment \\
\hline \multirow[t]{2}{*}{ Secondary education } & 0.385 & 0.073 & 0.372 & 0.092 \\
\hline & $(1.62)$ & $(0.22)$ & $(1.58)$ & $(0.27)$ \\
\hline \multirow[t]{2}{*}{ University education } & 1.252 & 0.418 & 1.244 & 0.430 \\
\hline & $(5.62)$ & $(1.52)$ & $(5.62)$ & $(1.55)$ \\
\hline \multirow[t]{2}{*}{ Age } & 0.337 & 0.165 & 0.338 & 0.163 \\
\hline & $(5.22)$ & $(2.16)$ & $(5.22)$ & $(2.14)$ \\
\hline \multirow[t]{2}{*}{ Age squared } & -0.003 & -0.002 & -0.003 & -0.002 \\
\hline & $(4.97)$ & $(2.37)$ & $(4.98)$ & $(2.34)$ \\
\hline \multirow[t]{2}{*}{$\Delta \ln \widehat{H P}_{t+5, t}-i^{1}$} & 5.356 & 4.287 & 6.555 & 2.497 \\
\hline & $(3.17)$ & $(2.19)$ & $(3.17)$ & (1.09) \\
\hline \multirow{2}{*}{ Volatility $_{t+5}^{2}$} & - & - & 0.293 & -0.495 \\
\hline & & & $(1.09)$ & $(1.82)$ \\
\hline \multirow[t]{2}{*}{ Previous other housing } & -0.561 & 0.215 & -0.564 & 0.219 \\
\hline & $(1.93)$ & $(0.89)$ & $(1.93)$ & $(0.90)$ \\
\hline \multirow[t]{2}{*}{ Constant } & -13.2415 & -9.339 & -13.441 & -9.026 \\
\hline & $(8.88)$ & $(5.09)$ & $(8.76)$ & $(4.92)$ \\
\hline No. of observations & \multicolumn{2}{|c|}{41,589} & \multicolumn{2}{|c|}{41,589} \\
\hline No. by use of property & 399 & 267 & 399 & 267 \\
\hline McFadden's Pseudo $\mathrm{R}^{2}$ & \multicolumn{2}{|c|}{0.040} & \multicolumn{2}{|c|}{0.042} \\
\hline
\end{tabular}

${ }^{1}$ Aggregate $H P$ and $i$

${ }^{2}$ Five year ahead standard deviation of $H P$ from the $\mathrm{AR}(2) \mathrm{ARCH}(1)$ model $t$-ratios in parentheses; No. of observations are averages over the five imputed datasets 
The effects of education and age are stronger on the demand for consumption of secondary housing than on the demand for investment in secondary housing. The effect of the expected return is positive in both cases but better determined for consumption demand than for investment demand. Alternative return measures that could be thought more appropriate for investor type households were explored. In particular, I considered an index of the Madrid stock exchange as an alternative to the aggregate interest rate and expectations about housing changes two years ahead instead of five years ahead. The effects of returns remain better determined for consumption demand than for investment demand. ${ }^{27}$

The positive (but imprecise) effect of risk on consumption demand would point to a hedging effect while the negative effect on investment demand would correspond to the effect of an increase in financial risk. Table 5 reports the effects of volatility using the model based measure. Estimates based on observed volatility were broadly similar and results are available in the supplementary appendix.

Owning already some secondary housing has plausibly different effects depending on the use of the housing purchased. The effect is negative for the probability of purchasing other housing for the household own consumption while it has no effect in the case of purchase for investment use.

Duration dependence Duration dependence is not easy to model as a priori it may be expected to follow a non-linear pattern of low hazards at short durations, followed by higher hazards at intermediate durations and low hazards again at very long durations. Moreover, patterns are expected to differ for first time buyers of secondary property and for subsequent purchases. To try and capture these effects we included indicators of short durations (up to six years) for both first and subsequent secondary purchase hazards. As expected there is a significative negative effect for first purchases using retrospective data. However, for subsequent purchases the effect is positive but not significant. A similar pattern is observed for the within waves estimates although significance is lower. As for the multinomial models, duration dependence is confined to consumption motive but no effects appear for investment motive. The addition of these duration dependence effects did not alter in any way the effects of other variables. A full set of results are shown in the appendix.

\footnotetext{
${ }^{27} \mathrm{~A}$ table with the results for those alternative measures is available in the supplementary appendix.
} 


\subsection{Purchase probabilities over the sample period}

Table 6 reports logit estimates using purchase sequences for the sample period. For these sequences, I observe if a home-owner household has bought a new main residence. Thus, Table 6 presents results for both secondary and main housing purchase hazards.

Table 6

Hazards for the timing of housing purchases Main and other housing 2002-06

\begin{tabular}{|c|c|c|c|c|c|c|}
\hline \multirow{3}{*}{ Secondary education } & \multicolumn{3}{|c|}{ Other } & \multicolumn{3}{|c|}{ Main } \\
\hline & 0.408 & 0.411 & 0.381 & 0.164 & 0.170 & 0.156 \\
\hline & $(1.62)$ & $(1.64)$ & $(1.51)$ & $(0.39)$ & $(0.41)$ & $(0.37)$ \\
\hline \multirow[t]{2}{*}{ University education } & 0.809 & 0.811 & 0.773 & -0.146 & -0.138 & -0.154 \\
\hline & $(3.58)$ & $(3.59)$ & $(3.41)$ & $(0.34)$ & $(0.32)$ & $(0.36)$ \\
\hline \multirow[t]{2}{*}{ Age } & 0.095 & 0.096 & 0.092 & 0.090 & 0.090 & 0.090 \\
\hline & $(1.61)$ & $(1.62)$ & $(1.55)$ & $(0.83)$ & $(0.83)$ & $(0.83)$ \\
\hline \multirow[t]{2}{*}{ Age squared } & -0.001 & -0.001 & -0.001 & -0.001 & -0.001 & -0.001 \\
\hline & $(2.12)$ & $(2.13)$ & $(2.07)$ & $(1.12)$ & $(1.13)$ & $(1.12)$ \\
\hline \multirow[t]{2}{*}{ Married } & 0.718 & 0.715 & 0.739 & - & - & - \\
\hline & $(2.42)$ & $(2.41)$ & $(2.49)$ & & & \\
\hline$\Delta \ln H P_{t, t-1}-i_{\text {incomegroup }}^{1}$ & 12.929 & - & - & 15.491 & - & - \\
\hline \multirow{2}{*}{$\Delta \ln \widehat{H P}_{t+5, t}-i_{\text {incomegroup }}$} & $(2.00)$ & 13.010 & 15.609 & ) & 13.840 & 14.961 \\
\hline & & $(2.33)$ & $(2.70)$ & & $(1.26)$ & $(1.30)$ \\
\hline \multirow{2}{*}{$\begin{array}{l}\text { Income } \\
\text { (in million euro) }\end{array}$} & 0.440 & 0.440 & 0.430 & 0.400 & 0.410 & 0.410 \\
\hline & $(1.46)$ & $(1.47)$ & $(1.42)$ & $(0.54)$ & $(0.56)$ & $(0.55)$ \\
\hline \multirow{2}{*}{$\begin{array}{l}\text { Unemployment rate } \\
\text { (province) }\end{array}$} & - & - & -0.043 & - & - & -0.010 \\
\hline & & & $(1.82)$ & & & $(0.25)$ \\
\hline \multirow{2}{*}{$\begin{array}{l}\Delta \operatorname{lnIncome} \\
\text { (province) }\end{array}$} & - & - & 1.222 & - & - & 5.658 \\
\hline & & & $(0.21)$ & & & $(0.49)$ \\
\hline \multirow[t]{2}{*}{ Previous other housing } & 0.337 & 0.336 & 0.324 & - & - & - \\
\hline & $(1.75)$ & $(1.75)$ & $(1.68)$ & & & \\
\hline \multirow[t]{2}{*}{ Constant } & -8.235 & -8.164 & -7.908 & -8.388 & -8.143 & -8.315 \\
\hline & $(4.99)$ & $(4.91)$ & $(4.68)$ & $(2.75)$ & $(2.66)$ & 2.63 \\
\hline McFadden's Pseudo $\mathrm{R}^{2}$ & 0.064 & 0.063 & 0.065 & 0.032 & 0.030 & 0.031 \\
\hline No. of observations & 8,631 & 8,631 & 8,631 & 8,967 & 8,967 & 8,967 \\
\hline of which Purchases & 125 & 125 & 125 & 36 & 36 & 36 \\
\hline
\end{tabular}

${ }^{1}$ Aggregate $H P ; i$ by 6 income groups

$t$-ratios in parentheses; No. of observations are averages over the five imputed datasets

First we examine the results corresponding to the other housing purchase hazards (columns 1 to 3$)$. The estimated effect of university education is similar to the one for retrospective 
purchases but less significant, probably because of the inclusion of income. ${ }^{28}$ The age effect is also positive for most of the range but smaller and less significant than before. Being married has a strong positive effect on the probability of buying second housing. The effect of current income is small and not very significant. Other demographic controls like the presence of children, their age, size of the municipality and others were tried but were not significant and did not alter the results. ${ }^{29}$

In contrast, the effect of the housing return is strong and larger than the effect found for retrospective purchases. ${ }^{30}$ To evaluate the economic significance of the estimated coefficient we calculate to what extent the recently observed after-sample drop in aggregate purchases could be predicted by the estimated model. Hence, for each household in the sample we calculate the probability of purchase in 2005 using the estimates in column 2. We then replace the 2005 expected return (0.088 on average) by the one in 2009 (0.015 on average). ${ }^{31}$ Using the population weights this predicts a $61 \%$ fall in the number of purchases between 2005 and 2009. ${ }^{32}$ The aggregate number of housing transactions according to the National Stats Office fell by $58 \%$. Therefore, changes in expectations of rates of return are able to predict the fall in aggregate purchases between 2005 and 2009. This aggregate change corresponds to the average annual probability of purchasing other housing falling from $1.1 \%$ in 2005 to $0.4 \%$ in $2009 .^{33}$

To check whether the expected return is not capturing other market conditions effects, in the third (and 6th) column we introduce income growth and unemployment rate both at the province level. The effect of the housing return if anything is reinforced. We have also added 50 province dummies to the specification in column 2 and the results were unchanged. ${ }^{34}$

In the 4 th to 6 th column I report results for the purchase of a new main residence. The effects are not significant probably due to the small number of such transactions. However, the effect of the expected return is surprisingly similar to the one found for other housing purchases.

\footnotetext{
${ }^{28}$ We use the two observations on annual household income in the 2002 and 2005 waves to linearly extrapolate income for the in-between years.

${ }^{29}$ Detailed estimates with additional controls can be found in the supplementary appendix.

${ }^{30}$ In the next section we will see that the effect of housing returns is heterogeneous in important dimensions, which may explain the difference of estimated effects in the two periods.

${ }^{31}$ Note that the return variable varies with income through the interest rate.

${ }^{32}$ This corresponds to the fall in the purchases of secondary housing. Purchases because of a change in main housing fell by $63.4 \%$.

${ }^{33}$ Correspondingly, average times to purchase increased from 92 to 236 years.

${ }^{34}$ Results are reported in the appendix.
} 
The competing risks model estimated for this period provides in general similar results for consumption and for investment use and are reported in the supplementary appendix. One exception is the effect of already owning other housing. In this case, the positive effect found in Table 6 is the result of a significantly positive effect on the probability of investment purchase and a negative non significant effect in the case of own consumption purchases. The non-model based volatility measure has again a significantly negative effect on investment demand and a non significant but positive effect on consumption demand. The non-model based volatility measure was used instead of the one derived from the $\mathrm{AR}(2) \mathrm{ARCH}(1)$ model because the latter captures almost no variation for the period 2002-2006.

Table 7

Evidence of adjustment costs in housing purchases Main and other housing 2002-2006

\begin{tabular}{|c|c|c|}
\hline & Other housing & Main housing \\
\hline \multirow[t]{2}{*}{ Secondary education } & 0.387 & 0.144 \\
\hline & $(1.54)$ & $(0.34)$ \\
\hline \multirow[t]{2}{*}{ University education } & 0.759 & -0.199 \\
\hline & $(3.34)$ & $(0.46)$ \\
\hline \multirow[t]{2}{*}{ Age } & 0.090 & 0.083 \\
\hline & $(1.55)$ & $(0.78)$ \\
\hline \multirow[t]{2}{*}{ Age squared } & -0.001 & -0.001 \\
\hline & $(2.08)$ & $(1.09)$ \\
\hline \multirow[t]{2}{*}{ Married } & 0.703 & - \\
\hline & $(2.37)$ & \\
\hline \multirow{2}{*}{$\Delta \ln \widehat{H P}_{t+5, t}-i_{\text {incomegroup }}^{1}$} & 12.043 & 12.791 \\
\hline & $(2.17)$ & $(1.17)$ \\
\hline Income & 0.320 & 0.270 \\
\hline (in million euro) & $(1.00)$ & $(0.30)$ \\
\hline Proportion of & -0.788 & -0.717 \\
\hline housing wealth & $(2.13)$ & $(1.10)$ \\
\hline \multirow[t]{2}{*}{ Previous other housing } & 0.282 & - \\
\hline & $(1.46)$ & \\
\hline \multirow[t]{2}{*}{ Constant } & -7.256 & -7.254 \\
\hline & $(4.28)$ & $(2.33)$ \\
\hline McFadden's Pseudo R ${ }^{2}$ & 0.066 & 0.032 \\
\hline No. of observations & 8,631 & 8,967 \\
\hline Purchase & 125 & 36 \\
\hline No purchase & 8,506 & 8,931 \\
\hline
\end{tabular}

${ }^{1}$ Aggregate $H P ; i$ by 6 income groups

$t$-ratios in parentheses

No. of observations are averages over the five imputed datasets 
Testing for lumpy adjustment from purchase probabilities Finally, I consider a purchase hazard model that includes the ratio of housing wealth to total wealth at the beginning of the period as an independent variable. An $(S, s)$ rule expressed in terms of this ratio predicts that the probability of purchase increases when the ratio is too low. The results in Table 7 motivate those in Section 4.

According to an $(S, s)$ model we would expect such a variable to attract a negative sign in an equation of purchases and this is indeed what we find. A high value of the ratio of the stock of housing to wealth makes households less likely to purchase other housing. For main housing purchases the effect is again remarkably similar. The effects of the other variables are similar to those reported in Table 6 .

\subsection{Heterogeneous responses to expected returns ${ }^{35}$}

Type of household: education and income The evidence presented so far reveals a strong effect of expectations formed on the basis of past and current returns. A relevant question is whether this behavior varies with wealth or other (non-endogenous) measure of investor sophistication (Vissing-Jorgensen (2003) addresses this question for expected stock market returns).

To test this hypothesis we interact our expected return measure with education dummies in the analysis of retrospective purchase histories and with (log) income for the sample period of our panel (2002-2006). We find evidence of a stronger effect of expected returns on purchase probabilities for University graduates in the retrospective analysis and an effect growing significantly with income for the sample period. The estimated effects on the logistic purchase index are as follows:

Effect of expected returns on retrospective purchases:

$(3.447+5.010 *$ University education $)\left(\Delta \ln \widehat{H P}_{t+5, t}-i\right)$

Effect of expected returns on between-wave purchases:

$(-81.382+8.218 * \ln$ Income $)\left(\Delta \ln \widehat{H P}_{t+5, t}-i_{\text {incomegroup }}\right)$

$(t-$ ratios in parentheses $)$

\footnotetext{
${ }^{35}$ Full tables with the results described in this sub-section can be found in the supplementary appendix.
} 
These findings indicate that the estimated effect of extrapolative expected returns is not driven by information costs but may reveal more rational "jump on the bandwagon" strategy effects. The presence of such effects would help explain house price developments during housing booms. Following the argument in De Long et al. (1990), in the presence of some poorly informed households that extrapolate past changes into the future, more rational households may find it beneficial to purchase in anticipation of further purchases by less well informed households. ${ }^{36}$

Extent of house price overvaluation Here we study whether the effect of expected returns varies depending on how far from its fundamental determinants house prices are. To do so we have taken deviations of observed house prices with respect to the Banco de España long run model as a measure of over (or under) valuation and we have added an interaction with our expected returns measure. ${ }^{37}$

We find evidence of the effect of returns diminishing with overvaluation but the effect stays positive for the entire period. The estimated effect on the logistic purchase index is:

$$
\text { (4.390 - 9.431* overvaluation) }\left(\Delta \ln \widehat{H P}_{t+5, t}-i\right)
$$

The top values for our overvaluation measure are reached in 1991 (at 0.41) and 2006 (at $0.40)$

Interestingly, the interaction effect of overvaluation can be rationalized in the presence of heterogeneous beliefs about future house prices. Suppose that only a fraction of (optimistic) households have adaptive expectations about house prices returns, but this fraction depends negatively on the extent of overvaluation (the higher the overvaluation the smaller the fraction of households that remain optimistic about further price increases). In these circumstances we would expect the positive effect of housing returns on purchase probabilities to decline with overvaluation, just as we estimated it to be.

Positive vs. negative expected returns Finally, we find significative asymmetric effects of expected returns: strongly positive when positive expected returns are expected

\footnotetext{
${ }^{36}$ See De Long et al. (1990) for detail on how momentum traders may have substantial impact on stock prices and threaten the efficiency of financial markets.

${ }^{37}$ We use an updated version of the preferred model described in Martínez Pagés and Maza (2003) and reproduced in the appendix.
} 
and weak (mildly negative) when the expectation is a negative return. Taken literally, these results imply that changes in expected returns have no (or negative) effect on purchases in periods when returns are negative, and positive effects in periods when returns are positive, which are much larger than those predicted by the symmetric model.

These effects are: $9.474 * \operatorname{positive}\left(\Delta \ln \widehat{H P}_{t+5, t}-i\right)$ and $-3.596 *$ negative $\left(\Delta \ln \widehat{H P}_{t+5, t}-\right.$ i)with $t$-ratios of 5.72 and 2.09, respectively. Once again, such non-linearity highlights the limitations of simple models of expectations and is consistent with the existence of a role for the probability of overvaluation shown above.

\subsection{Sales hazards}

We cannot estimate annual hazards for the timing of sales between waves since we do not know in which of the between waves year the sale did take place. However, we can still estimate a time-aggregated hazard for the probability of a sale over the three-year period between waves conditioned on holding other housing at the beginning of the period. Table 8 reports logistic probabilities of sales for households which owned exactly one other property at the beginning of the period (in addition to main housing). We do not report sale hazards for households with more than one other property due to small samples and did not combine the two either because we expected different responses for each.

The signs of the estimated effects on the time aggregated hazard of a sale (in column 1) are as expected and the opposite of the previously estimated effects on the hazard of a purchase. Moreover, the results (signs and magnitudes) are robust across various specifications, but according to the standard errors the estimates are very imprecise. This is not surprising for the estimated effect of the expected return, since we can only rely on cross-sectional variation in returns. In contrast, the effect of age is more precise and shows that households are less likely to sell as they age until they are around 50 when the probability of a sale starts increasing as they grow older.

In column 2 of the Table we report equivalent estimates for time-aggregated purchases for comparison, which are broadly consistent with the earlier annual hazard estimates but have much larger standard errors. 
Table 8

Sales and purchases of secondary housing

Time-aggregated hazards over the three year period between waves

\begin{tabular}{|c|c|c|}
\hline & Sales & Purchases \\
\hline Secondary education & $\begin{array}{c}-0.608 \\
(0.91)\end{array}$ & $\begin{array}{l}0.168 \\
(0.39)\end{array}$ \\
\hline University education & $\begin{array}{c}-0.371 \\
(0.54)\end{array}$ & $\begin{array}{l}0.479 \\
(0.47)\end{array}$ \\
\hline Age & $\begin{array}{l}-0.209 \\
(1.73)\end{array}$ & $\begin{array}{l}0.124 \\
(1.06)\end{array}$ \\
\hline Age squared & $\begin{array}{l}0.002 \\
(1.68)\end{array}$ & $\begin{array}{l}-0.002 \\
(1.64)\end{array}$ \\
\hline Married & $\begin{array}{c}-0.043 \\
(0.08)\end{array}$ & $\begin{array}{l}0.998 \\
(1.35)\end{array}$ \\
\hline$\Delta \ln \widehat{H P_{2007,2002}}-i_{\text {incomegroup }}^{1}$ & $\begin{array}{c}-6.076 \\
(0.47)\end{array}$ & $\begin{array}{l}2.537 \\
(0.30)\end{array}$ \\
\hline $\begin{array}{l}\text { Income }_{2002} \\
\text { (in million euro) }\end{array}$ & $\begin{array}{c}-6.500 \\
(0.50)\end{array}$ & $\begin{array}{l}7.700 \\
(1.42)\end{array}$ \\
\hline Constant & $\begin{array}{l}5.680 \\
(1.82)\end{array}$ & $\begin{array}{c}-6.497 \\
(2.06)\end{array}$ \\
\hline McFadden's Pseudo R ${ }^{2}$ & 0.093 & 0.107 \\
\hline No. of observations & 636 & 2,442 \\
\hline of which sales & 178 & - \\
\hline of which purchases & - & 120 \\
\hline
\end{tabular}

${ }^{1}$ Province $H P$ in $2002 ; i$ by 6 income groups in 2002

$t$-ratios in parentheses; No. of observations are averages over the five imputed datasets

\section{An $(S, s)$ model of housing transactions}

\subsection{The model}

Theoretical context Consumers choose when and how much housing to purchase in order to maximize the present value of utility. Since households purchase (and sale) housing very infrequently, I consider an $(S, s)$ model of lumpy adjustment, which is a standard model of discrete and infrequent adjustment. The idea is that there are large and lumpy transaction costs involved in housing transactions (search costs, intermediation fees, taxes). These costs together with indivisibilities in the stock make it impossible for households to make frequent and small adjustments to their housing stock in response to fluctuations in prices.

The seminal theoretical reference is the transaction cost model of Grossman and Laroque (1990) who consider portfolio choice when, in addition to a risky asset and a riskless asset, there is a component of wealth that yields consumption benefits (a durable good such as 
housing or art), the durable good being the sole argument in the utility function. ${ }^{38}$ In the absence of frictions, the model yields a proportional stock rule, where the ratio of the durable stock to wealth depends positively on the net return (of housing), ${ }^{39}$ and negatively on the risk-free interest rate and the ratio of the expected excess return of the risky asset to its standard deviation. In the presence of transaction costs of a particular form, ${ }^{40}$ the model continues to deliver a proportional stock rule in which housing is allowed to deviate from its optimal share of wealth until some threshold is reached, at which point the housing stock is adjusted to the optimal target share.

More realistic assumptions typically imply consideration of more than one state variable. So here I just regard the $(S, s)$ model as a simple empirical specification, which allows me to separate out effects on optimal housing in the absence of adjustment costs from effects on the inaction range.

The EFF data contain separate information on the values of primary and secondary housing wealth. Therefore, it may be possible in principle to consider primary and secondary housing as two different durable goods in the utility function. However, such an extension seems impractical in these data since most of the adjustment of EFF households during the sample period takes place through secondary housing. Moreover, the statistical simplicity of the basic model would be lost.

In my model I express the $(S, s)$ rule in terms of the ratio of housing wealth to total gross wealth. Other papers in the durable consumption literature have used permanent income (Lam, 1991) or non-durable consumption (Attanasio, 2000) as alternatives to total wealth, partly due to measurement problems. Since the EFF contains detailed data on household asset holdings, using wealth seems a good alternative. I did try, however, alternative specifications but using the ratio to total wealth provided the most meaningful results.

There is a literature that attempts to distinguish empirically between investment demand for housing and consumption demand relying on housing tenure information (Ioannides and Rosenthal, 1994). We cannot directly do this for our data because a large majority of households are homeowners. Moreover, despite having information on whether secondary housing are held for consumption or investment we do not observe households renting secondary

\footnotetext{
${ }^{38}$ Flavin and Nakagawa (2008) consider a generalization of Grossman and Laroque (1990), featuring a utility function that includes nondurable consumption goods as well as the durable good as arguments.

${ }^{39}$ Given by the difference between the appreciation rate of the durable good and the riskless rate of return.

${ }^{40}$ See e.g. Eberly (1994).
} 
property, so extending the Ioannides-Rosenthal approach to secondary property does not seem relevant either. In addition, it is empirically difficult to distinguish between housing investment and housing consumption with a low rate of utilization in the case of secondary properties such as vacation or seasonal housing. In any case the Henderson-Ioannides (1983) constraint, which requires that the quantity of housing owned is at least as large as the quantity consumed, does not seem to be binding for EFF households.

The $(\mathbf{S}, \mathbf{s})$ model Let $d$ be an indicator of a positive or negative adjustment to the housing stock as a result of transactions between survey waves. Also let $y_{1}$ and $y_{2}$ denote the beginning-of-period and the end-of-period state variables (the housing to wealth ratios). Let $y^{*}$ be the target level, and $b^{u}$ and $b^{\ell}$ the positive and negative inaction thresholds, respectively. Therefore, according to the $(S, s)$ rule $y_{2}$ is set to the optimal target level (and therefore transactions take place) only if the beginning-of-period deviation from the target hits the band limits:

$$
y_{2}=\left\{\begin{array}{l}
y^{*} \text { if } y_{1}=b^{\ell} \text { or } y_{1}=b^{u} \\
\widetilde{y}_{2} \text { if } b^{\ell}<y_{1}<b^{u}
\end{array}\right.
$$

where $\widetilde{y}_{2}$ denotes the state variable process in the absence of action, so that $\widetilde{y}_{2}$ differs from $y_{1}$ as a result of appreciation or depreciation of the existing housing stock during the period and additions or substractions to the denominator (total wealth).

Following Attanasio (2000), the target level and bandwidth equations are specified as

$$
\begin{aligned}
y^{*} & =x^{\prime} \beta+\sigma u \\
b^{u} & =y^{*}+\exp \left(z^{\prime} \gamma_{u}+\omega v\right) \\
b^{\ell} & =y^{*}-\exp \left(z^{\prime} \gamma_{\ell}+\omega v\right)
\end{aligned}
$$

where $(u, v)$ are standard normal error terms independent of $\left(x, z, \widetilde{y}_{1}\right)$. In the basic model I assume a symmetric band $\left(\gamma_{u}=\gamma_{\ell}=\gamma\right)$ and uncorrelated errors $\left(\rho_{u v}=0\right)$. The model also assumes that the bands are observable, so that for active households $(d=1)$ we have

$$
\ln |\Delta y|=z^{\prime} \gamma+\omega v
$$

Otherwise, if $d=0$ we only observe the event $b^{\ell}<y_{1}<b^{u}{ }^{41}$

In this model the extent of adjustment is governed by the inaction range $e^{z^{\prime} \gamma+\omega v}$, which is allowed to depend on observable and unobservable heterogeneity through $z$ and $v$.

\footnotetext{
${ }^{41}$ A possibly more realistic but less tight version with unobservable bands could be developed as in Attanasio (2000).
} 


\subsection{Maximum likelihood estimation}

We have data on $\left\{d, y_{1}, y_{2}, x, z\right\}_{i=1}^{n}$. Note that estimation of the $(S, s)$ bandwidth requires observation of the housing stock before and after the adjustment, so panel data are essential, as are data on purchases and sales.

The likelihood of the sample is similar to a bivariate Tobit model with a complicated probability of censoring. That is, the likelihood contribution of active households $(d=1)$ is given by the joint density of $y_{2}$ and $\ln |\Delta y|$, whereas the contribution of inactive households is just the probability of inaction:

$$
\operatorname{Pr}\left(b^{\ell}<y_{1}<b^{u}\right)=\operatorname{Pr}\left[y_{1}-x^{\prime} \beta-\exp \left(z^{\prime} \gamma+\omega v\right)<\sigma u<y_{1}-x^{\prime} \beta+\exp \left(z^{\prime} \gamma+\omega v\right)\right]
$$

Since the probability of inaction is governed by the same equations as in the regression part of the model, this $(S, s)$ model does not require exclusion restrictions for semiparametric identification (as is the case of Heckman's selection model). Nevertheless, exclusion restrictions suggested by the economic model are that housing stock imbalance and non-convex transaction costs affect the timing but not the size of housing purchases.

The log likelihood of the sample is therefore given by

$$
\begin{aligned}
L= & \sum_{i=1}^{n}\left\{d_{i} \ln \left[\frac{1}{\sigma} \phi\left(\frac{y_{2 i}-x_{i}^{\prime} \beta}{\sigma}\right)\right]+d_{i} \ln \left[\frac{1}{\omega} \phi\left(\frac{\ln \left|\Delta y_{i}\right|-z_{i}^{\prime} \gamma}{\omega}\right)\right]\right. \\
& \left.+\left(1-d_{i}\right) \ln \int\left[\Phi\left(\frac{y_{1 i}-x_{i}^{\prime} \beta+\exp \left(s_{i}\right)}{\sigma}\right)-\Phi\left(\frac{y_{1 i}-x_{i}^{\prime} \beta-\exp \left(s_{i}\right)}{\sigma}\right)\right] \phi(v) d v\right\}
\end{aligned}
$$

where $s_{i}=z^{\prime} \gamma+\omega v, \phi($.$) is the standard normal density and \Phi($.$) the corresponding cdf.$

For this model $E(u \mid d=1)$ may be zero or close to it because of symmetry, so OLS estimates of the target equation in the subsample of active units may be consistent. However, since we expect $E(v \mid d=1) \neq 0$ and the fraction of inactive households is large, OLS estimates of the bandwidth equation may have large biases.

I used OLS as initial values and approximated the probability of inaction using GaussHermite integration with 30 points.

The scope of the analysis is limited by the fact that the period between observations of the state variable is longer that it would be desirable. Another limitation is due to having a two-wave panel only, which precludes consideration of random effects to allow for unobserved household heterogeneity. 


\section{$4.3 \quad(\mathrm{~S}, \mathrm{~s})$ rule results}

Table 9 presents ML estimates of the $(S, s)$ model. ${ }^{42}$ In the first part of the Table the estimates of the target level equation show that the expected return on housing wealth has a well determined positive effect on the proportion of wealth in housing households aim to hold. The size of the effect implies that the increase in the rate of return that occurred for example between 2002 and 2001 (around 2\%), would increase the target housing wealth ratio by 2.2 percentage points.

Both income and wealth (net of debts) have a significant negative effect on the target proportion of wealth held in housing. High income and wealth households hold more diversified portfolios. Housing appears thus as a "necessity" in terms of life-cycle wealth.

Table 9

Dynamic housing wealth demand Estimates of $(S, s)$ rule target and band

\begin{tabular}{lcc}
\hline Target level equation & & $t-$ ratio \\
\hline Self-employed & -0.190 & $(6.65)$ \\
Partner self-employed & -0.148 & $(3.57)$ \\
Head not working & -0.079 & $(4.02)$ \\
Other adult inactive & -0.053 & $(2.71)$ \\
$\Delta \ln \widehat{H P_{2007,2002}-i_{\text {incomegroup }}^{1}}$ & 1.115 & $(3.38)$ \\
Permanent income & -0.001 & $(4.21)$ \\
(in thousand euros) & & \\
Wealth & -0.063 & $(7.73)$ \\
(in million euros) & & \\
Constant & 0.917 & $(27.70)$ \\
Standard deviation & 0.179 & $(29.53)$ \\
\hline Bandwidth equation & & \\
\hline$\Delta \ln \hat{H P_{2007,2002}-i_{\text {incomegroup }}}$ & -2.323 & $(0.74)$ \\
Permanent income (in thousand euros) & -0.008 & $(2.78)$ \\
Wealth (in million euros) & -0.287 & $(2.97)$ \\
Constant & 0.717 & $(2.51)$ \\
Standard deviation & 2.231 & $(23.30)$ \\
\hline
\end{tabular}

${ }^{1}$ Province $H P$ in $2002 ; i$ rate by 6 income groups in 2002 .

No evidence of life-cycle patterns could be found beyond permanent income effects. In contrast, the situation of household members in the labour market reveals significant effects.

\footnotetext{
${ }^{42}$ Aside from purchases and sales, we include housing inheritances received during the sample period in the transaction indicator (ie. $d=1$ ) on the grounds that it may be anticipated to some extent. The $(S, s)$ model estimates reported in this section do not differ in any substantive way if instead we consider $d=0$ for those cases.
} 
Self-employment of the head of household or his partner have a sizeable negative effect probably due to wealth needed to run their own business. An unemployed (or inactive) household head reduces as well the target housing to wealth ratio although to a lesser extent than self-employment. Inactivity (but not unemployment) of other household members has a similar effect.

Turning to the results for the bandwidth equation (second part of Table 9), housing returns do not affect the inaction range. In contrast, income and wealth have a significant negative effect. This points to the prevalence of fixed transaction costs over proportional ones. Fixed transaction costs could be search and moving costs while some legal fees and taxes are to a large extent proportional to the value of the house purchased or sold.

Outstanding debt and the capacity to incur in debt may also play a role in the decision to purchase a new house. To control for this I construct the ratio of outstanding debt to gross total wealth which reflects the household capacity of acquiring more debt and is less endogenous in a purchase equation than the level of debt. However, the effect of debt capacity is insignificant, both in the target and in the band equations, and does not change the results. In the same vein, I added debt variables to the sample period hazard of buying a secondary property but they were insignificant. The results of various specifications including debt variables may be found in the appendix. ${ }^{43}$

Dunn (2003) for home purchases and Eberly (1994) for automobile purchases find that the $(S, s)$ bandwidth increases with income uncertainty. Income uncertainty is associated to type of occupation, like being self-employed. In the case of housing, I find an important effect of self-employment on the target equation but not on the bandwidth equation.

Taking together the results for the target level and the band-width equations we conclude that greater uncertainty or risk (as measured here by self-employment and unemployment) will have an effect on housing demand through a smaller target proportion of housing wealth rather than through a postponement of intended purchases or sales. The same can be said of the effect of changes in expected housing return rates that affect the desired housing wealth target ratio but not the inaction range. This last point is relevant because it implies that when expected returns on housing drop there is a reduction in the desired amount of housing

\footnotetext{
${ }^{43}$ Eberly (1994) finds negative effects for income and wealth in her bandwidth model for automobile purchases using a sample of credit constrained households but not for the non-constrained. This may be interpreted as high income and wealth allowing for more frequent adjustment when credit constrained. I have not pursued a splitting of the EFF sample due to the small number of purchases observed in my data.
} 
wealth. Falling returns do not mean just a delay in purchases as would be the case if the negative effect of the expected returns on purchase probabilities worked through the inaction range rather than through the target level.

Transaction probabilities Using the estimated $(S, s)$ model it is possible to calculate average derivative effects on the probability of a positive (or negative) adjustment to the housing stock between survey waves. In our data positive or negative adjustments are essentially associated to purchases or sales, respectively. Therefore, the probability of a positive adjustment in the $(S, s)$ model can be regarded as a semi-structural counterpart of the logistic purchase hazards in the previous section (aggregated over a three-year interval).

An individual's probability of a positive adjustment is given by

$$
\pi_{i}^{+}=1-\int \Phi\left(w_{i}^{+}\right) \phi(v) d v
$$

whereas the probability of a negative adjustment is

$$
\pi_{i}^{-}=\int \Phi\left(w_{i}^{-}\right) \phi(v) d v
$$

where $w_{i}^{+}=\left[y_{1 i}-x_{i}^{\prime} \beta+\exp \left(s_{i}\right)\right] / \sigma$ and $w_{i}^{-}=\left[y_{1 i}-x_{i}^{\prime} \beta-\exp \left(s_{i}\right)\right] / \sigma$. Thus, the derivative effect on $\pi_{i}^{+}$of a determinant $x_{j}$ with coefficient $\beta_{j}$ in the target equation and $\gamma_{j}$ in the bandwidth equation is given by

$$
\frac{\partial \pi_{i}^{+}}{\partial x_{j}}=\beta_{j} I_{i}^{+}-\gamma_{j} J_{i}^{+}
$$

where $I_{i}^{+}=\sigma^{-1} \int \phi\left(w_{i}^{+}\right) \phi(v) d v$ and $J_{i}^{+}=\sigma^{-1} \int \exp \left(s_{i}\right) \phi\left(w_{i}^{+}\right) \phi(v) d v$. Therefore, a positive effect on the target increases the probability of purchase whereas a positive effect on the bandwidth reduces this probability. The net effect is individual specific and depends on the values of $I_{i}^{+}$and $J_{i}^{+}$.

Turning to specific results, we can see that the average positive effect of permanent income on the logistic purchase probabilities is the net result of a negative effect on the desired fraction of housing wealth and a negative effect on the size of the inaction band. Counterbalancing effects are also observed for net wealth. Other determinants, notably the expected rate of return on housing, only affect purchase probabilities through their effect on the target level. So, as far as transaction probabilities is concerned, the $(S, s)$ analysis complements the logistic hazard results by providing a decomposition of total effects into effects on the target and effects on the bandwidth. 


\section{Concluding remarks}

In this paper I developed empirical models of the purchase behavior of main and secondary housing by Spanish households using the panel sample from the first two waves of the Spanish household finance survey (EFF). In particular, I estimated discrete hazard models using retrospective and within-period purchase sequences. I also estimated an $(S, s)$ model combining transactions data with longitudinal information on household wealth and housing stock values that allowed to identify separate effects of observable determinants on target values and inaction range in transaction probabilities.

I found a positive and significant effect on the demand for houses of the expected rate of return on housing based on the extrapolation of past price changes. This is true for historical and within-period purchase probabilities as well as for the target ratio of housing wealth to total wealth. Changes in expectations of rates of return are able to predict the fall in aggregate purchases between 2005 and 2009.

The results from the $(S, s)$ model show that the predicted decrease in the number of purchases after a fall in expected returns reflects a decrease in the target level of housing wealth and not a post-ponement in transactions.

Estimating a competing risks model of housing demand for consumption and investment use I find some evidence of a positive effect of increased risk on consumption demand (hedging motive) but a negative effect on investment demand (financial risk motive).

The effects of adaptive expectations of housing returns are in line with previous results in behavioral finance and momentum trading behavior. Modelling house prices is outside the scope of this paper but the estimated association between housing demand and recent house price growth (and its interaction with household education or income) is revealing about how house price frenzies may develop. 


\section{References}

[1] ANDREW, M., and G. MEEN (2003). "Housing Transactions and the Changing Decisions of Young Households in Britain: The Microeconomic Evidence", Real Estate Economics, 31, pp. 117-138.

[2] ATtANASIO, O. (2000). "Consumer Durables and Inertial Behaviour: Estimation and Aggregation of (S, s) Rules for Automobile Purchases", Review of Economic Studies, 67, pp. 667-696.

[3] BAJARI, P., P. CHAN, D. KRUEGER and D. MilleR (2010). A Dynamic Model of Housing Demand: Estimation and Policy Implications, NBER Working Paper No. 15955 .

[4] BANKS, J., R. BLUNDELL, Z. OLDFIELD and J. SMITH (2010). House Price Volatility and the Housing Ladder, IZA Discussion Paper No. 5173.

[5] BOVER, O. (2004). The Spanish Survey of Household Finances (EFF): description and methods of the 2002 Wave, Occasional Paper No. 0409, Banco de España.

[6] - (2008). The dynamics of household income and wealth: results from the panel of the Spanish Survey of Household Finances (EFF) 2002-2005, Occasional Paper No. 0810, Banco de España.

[7] BOVER, O., C. MARTÍNEZ-CARRASCAL and P. VELILLA (2005). "The wealth of Spanish households: a microeconomic comparison with the United States, Italy and the United Kingdom", Economic Bulletin, July, Banco de España.

[8] CASE, K. E., and R. J. SHILLER (1989). "The Efficiency of the Market for SingleFamily Homes", The American Economic Review, 79, pp. 125-137.

[9] DE LONG, J. B., A. SCHLEIFER, L. H. SUMMERS and R. J. WALDMANN (1990). "Positive Feedback Investment Strategies and Destabilizing Rational Speculation", The Journal of Finance, 45, pp. 379-395.

[10] DUNN, W. E. (2003). "The Effects of Precautionary Saving Motives on (S, s) Bands for Home Purchases", Regional Science and Urban Economics, 33, pp. 467-488.. 
[11] EBERLY, J. C. (1994). "Adjustment of Consumers' Durables Stocks: Evidence from Automobile Purchases", Journal of Political Economy, 102, pp. 403-436.

[12] FERNANDEZ-CORUGEDO, E., and J. MUELLBAUER (2006). Consumer Credit Conditions in the UK, Bank of England Working Paper No. 314.

[13] FLAVIN, M., and S. NAKAGAWA (2008). "A model of Housing in the Presence of Adjustment Costs: A Structural Interpretation of Habit Persistence", The American Economic Review, 98, pp. 474-495..

[14] Grossman, S. J., and G. LAROQUE (1990). "Asset Pricing and Optimal Portfolio Choice in the Presence of Illiquid Durable Consumption Goods", Econometrica, 58, pp. $25-51$.

[15] GUISO, L., and T. JAPPELLI (2002). "Private Transfers, Borrowing Constraints and the Timing of Homeownership", Journal of Money, Credit, and Banking, 34, pp. 315339 .

[16] HAN, L. (2009). "The Effects of Price Uncertainty on Housing Demand: Empirical Evidence from U.S. Markets", Review of Financial Studies, forthcoming.

[17] HENDERSON, J. V., and Y. M. IOANNIDES (1983). "A model of housing tenure choice", The American Economic Review, 73, pp. 98-113.

[18] HUI, E. C. M. (2004). "BRE Index for the Hong-Kong Residential Property Market", International Journal of Strategic Property Management.

[19] HWANG, M., and J. M. QUIGLEY (2006). "Economic Fundamentals in Local Housing Markets: Evidence from U.S. Metropolitan Regions", Journal of Regional Science, 46, pp. $425-453$.

[20] IOANNIDES, Y., and S. ROSENTHAL (1994). "Estimating the Consumption and Investment Demands for Housing and Their Effect on Housing Tenure Status", Review of Economics and Statistics, 76, pp. 127-141.

[21] LAM, P.-S. (1991). "Permanent Income, Liquidity, and Adjustments of Automobile Stocks", Quarterly Journal of Economics, 106, pp. 203-230. 
[22] MARTÍNEZ PAGÉS, J., and L. Á. MAZA (2003). Análisis del precio de la vivienda en España, Working Paper No. 0307, Banco de España.

[23] OXFORD ECONOMICS (2009). Developing Analytical methods for the Identification of Imbalance and Risks in the EU Housing Markets, Final report.

[24] PIAZZESI, M., and M. SCHNEIDER (2009). "Momentum Traders in the Housing Market: Survey Evidence and a Search Model", American Economic Review, Papers 85 Proceedings, 99, pp. 406-411.

[25] VISSING-JORGEnSEN, A. (2003). Perspectives on Behavioral Finance: Does "Irrationality" Disappear with Wealth? Evidence from Expectations and Actions, NBER Macroeconomics Annual. 


\section{BANCO DE ESPAÑA PUBLICATIONS}

\section{WORKING PAPERS ${ }^{1}$}

0922 GALO NUÑO: Technology, convergence and business cycles.

0923 FRANCISCO DE CASTRO AND JOSÉ LUIS FERNÁNDEZ: The relationship between public and private saving in Spain: does Ricardian equivalence hold?

0924 GONZALO FERNÁNDEZ-DE-CÓRDOBA, JAVIER J. PÉREZ AND JOSÉ L. TORRES: Public and private sector wages interactions in a general equilibrium model.

0925 ÁNGEL ESTRADA AND JOSÉ MANUEL MONTERO: R\&D investment and endogenous growth: a SVAR approach.

0926 JUANA ALEDO, FERNANDO GARCÍA-MARTÍNEZ AND JUAN M. MARÍN DIAZARAQUE: Firm-specific factors influencing the selection of accounting options provided by the IFRS: Empirical evidence from Spanish market.

0927 JAVIER ANDRÉS, SAMUEL HURTADO, EVA ORTEGA AND CARLOS THOMAS: Spain in the euro: a general equilibrium analysis.

0928 MAX GILLMAN AND ANTON NAKOV: Monetary effects on nominal oil prices.

0929 JAVIER MENCÍA AND ENRIQUE SENTANA: Distributional tests in multivariate dynamic models with Normal and Student $t$ innovations.

0930 JOAN PAREDES, PABLO BURRIEL, FRANCISCO DE CASTRO, DANIEL GARROTE, ESTHER GORDO AND JAVIER J. PÉREZ: Fiscal policy shocks in the euro area and the US: an empirical assessment.

0931 TERESA LEAL, DIEGO J. PEDREGAL AND JAVIER J. PÉREZ: Short-term monitoring of the Spanish Government balance with mixed-frequencies models.

0932 ANTON NAKOV AND GALO NUÑO: Oilgopoly: a general equilibrium model of the oil-macroeconomy nexus.

0933 TERESA LEAL AND JAVIER J. PÉREZ: Análisis de las desviaciones presupuestarias aplicado al caso del presupuesto del Estado.

0934 JAVIER J. PÉREZ AND A. JESÚS SÁNCHEZ: Is there a signalling role for public wages? Evidence for the euro area based on macro data.

0935 JOAN PAREDES, DIEGO J. PEDREGAL AND JAVIER J. PÉREZ: A quarterly fiscal database for the euro area based on intra-annual fiscal information.

1001 JAVIER ANDRÉS, ÓSCAR ARCE AND CARLOS THOMAS: Banking competition, collateral constraints and optimal monetary policy.

1002 CRISTINA BARCELÓ AND ERNESTO VILLANUEVA: The response of household wealth to the risk of losing the job: evidence from differences in firing costs.

1003 ALEXANDER KARAIVANOV, SONIA RUANO, JESÚS SAURINA AND ROBERT TOWNSEND: No bank, one bank, several banks: does it matter for investment?

1004 GABRIEL PEREZ-QUIROS AND HUGO RODRÍGUEZ MENDIZÁBAL: Asymmetric standing facilities: an unexploited monetary policy tool.

1005 GABRIEL JIMÉNEZ, JOSE A. LOPEZ AND JESÚS SAURINA: How does competition impact bank risk-taking?

1006 GIUSEPPE BERTOLA, AURELIJUS DABUSINSKAS, MARCO HOEBERICHTS, MARIO IZQUIERDO, CLAUDIA KWAPIL, JEREMI MONTORNĖS AND DANIEL RADOWSKI: Price, wage and employment response to shocks: evidence from the WDN Survey.

1007 JAVIER MENCÍA: Testing non-linear dependence in the Hedge Fund industry.

1008 ALFREDO MARTÍN-OLIVER: From proximity to distant banking: Spanish banks in the EMU.

1009 GALO NUÑO: Optimal research and development expenditure: a general equilibrium approach.

1010 LUIS J. ÁLVAREZ AND PABLO BURRIEL: Is a Calvo price setting model consistent with micro price data?

1011 JENS HAGENDORFF, IGNACIO HERNANDO, MARÍA J. NIETO AND LARRY D. WALL: What do premiums paid for bank M\&As reflect? The case of the European Union.

1012 DAVID DE ANTONIO LIEDO: General equilibrium restrictions for dynamic factor models.

1013 JAMES COSTAIN, JUAN F. JIMENO AND CARLOS THOMAS: Employment fluctuations in a dual labor market.

1014 LUIS M. VICEIRA AND RICARDO GIMENO: The euro as a reserve currency for global investors.

1015 PALOMA LÓPEZ-GARCÍA AND JOSÉ MANUEL MONTERO: Understanding the Spanish business innovation gap: The role of spillovers and firms' absorptive capacity.

1. Previously published Working Papers are listed in the Banco de España publications catalogue. 
1016 AITOR LACUESTA AND SERGIO PUENTE: El efecto del ciclo económico en las entradas y salidas de inmigrantes en España.

1017 REBEKKA CHRISTOPOULOU, JUAN F. JIMENO AND ANA LAMO: Changes in the wage structure in EU countries.

1018 THOMAS BREUER, MARTIN JANDAČKA, JAVIER MENCÍA AND MARTIN SUMMER: A systematic approach to multi-period stress testing of portfolio credit risk.

1019 LUIS J. ÁLVAREZ AND PABLO BURRIEL: Micro-based estimates of heterogeneous pricing rules: The United States vs. the euro area.

1020 ALFREDO MARTÍN-OLIVER AND VICENTE SALAS-FUMÁS: I.T. investment and intangibles: Evidence from banks.

1021 LUISA LAMBERTINI, CATERINA MENDICINO AND MARIA TERESA PUNZI: Expectations-driven cycles in the housing market.

1022 JULIÁN MESSINA, PHILIP DU CAJU, CLÁUDIA FILIPA DUARTE, NIELS LYNGGÅRD HANSEN AND MARIO IZQUIERDO: The incidence of nominal and real wage rigidity: an individual-based sectoral approach.

1023 ALESSIO MORO: Development, growth and volatility.

1024 LUIS J. ÁLVAREZ AND ALBERTO CABRERO: Does housing really lead the business cycle?

1025 JUAN S. MORA-SANGUINETTI: Is judicial inefficiency increasing the house property market weight in Spain? Evidence at the local level.

1026 MAXIMO CAMACHO, GABRIEL PEREZ-QUIROS AND PILAR PONCELA: Green shoots in the Euro area. A real time measure.

1027 AITOR ERCE AND JAVIER DÍAZ-CASSOU: Creditor discrimination during sovereign debt restructurings.

1028 RAFAEL REPULLO, JESÚS SAURINA AND CARLOS TRUCHARTE: Mitigating the pro-cyclicality of Basel II.

1029 ISABEL ARGIMÓN AND JENIFER RUIZ: The effects of national discretions on banks.

1030 GABRIEL JIMÉNEZ, STEVEN ONGENA, JOSÉ-LUIS PEYDRÓ AND JESÚS SAURINA: Credit supply: identifying balance-sheet channels with loan applications and granted loans.

1031 ENRIQUE MORAL-BENITO: Determinants of economic growth: A Bayesian panel data approach.

1032 GABE J. DE BONDT, TUOMAS A. PELTONEN AND DANIEL SANTABÁRBARA: Booms and busts in China's stock market: Estimates based on fundamentals.

1033 CARMEN MARTÍNEZ-CARRASCAL AND JULIAN VON LANDESBERGER: Explaining the demand for money by nonfinancial corporations in the euro area: A macro and a micro view.

1034 CARMEN MARTÍNEZ-CARRASCAL: Cash holdings, firm size and access to external finance. Evidence for the euro area.

1035 CÉSAR ALONSO-BORREGO: Firm behavior, market deregulation and productivity in Spain.

1036 OLYMPIA BOVER: Housing purchases and the dynamics of housing wealth.

\section{BANCODEESPAÑA}

Eurosistema
Unidad de Publicaciones Alcalá, 522; 28027 Madrid

Telephone +34913386363. Fax +34913386488

E-mail: publicaciones@bde.es www.bde.es 